\title{
Effects of Dietary Linoleic and Linolenic Acids on Development and Adult Formation of Creatonotus gangis L.
}

\author{
Palash Mondal and Somen Chakraborty*
}

\author{
Department of Plant Protection, Palli Siksha Bhavana, Visva-Bharati, \\ Sriniketan, Birbhum, West Bengal-731236, India \\ *Corresponding author
}

\begin{tabular}{|c|c|}
\hline & A B S T R A C T \\
\hline $\begin{array}{l}\text { Adult formation, } \\
\text { Creatonotus } \\
\text { gangis, Linoleic } \\
\text { acid, Linolenic } \\
\text { acid. }\end{array}$ & \multirow{3}{*}{$\begin{array}{l}\text { An effort had been made to observe the effects of dietary linoleic and linolenic acids on } \\
\text { growth and development as well as on adult formation of Creatonotus gangis L. Six } \\
\text { different levels of both fatty acids viz. } 0.05 \mathrm{~g}, 0.075 \mathrm{~g}, 0.1 \mathrm{~g}, 0.125 \mathrm{~g}, 0.15 \mathrm{~g} \text { and } 0.2 \mathrm{~g} \text { per } \\
100 \mathrm{~g} \text { of basic diet were incorporated in rice based diet for rearing of the insect. The semi } \\
\text { synthetic diet without any fatty acid was taken as control which proved poor diet for the } \\
\text { insect while berseem, a natural food plant of this insect, performed better than other diets. } \\
\text { Experimental findings revealed that addition of linoleic and linolenic acids in the rice } \\
\text { based diet upto a certain level of concentration improved the growth and development } \\
\text { along with normal adult formation of the insect. It appeared that linoleic and linolenic } \\
\text { acids had almost similar effect on } C \text {. gangis. Results also revealed that } 0.15 \mathrm{~g} \text { of both fatty } \\
\text { acids was the most effective concentration for adult emergence and beyond that level they } \\
\text { acted negatively on biology of the insect. }\end{array}$} \\
\hline Article Info & \\
\hline $\begin{array}{l}\text { Accepted: } \\
\text { 29 May } 2017 \\
\text { Available Online: } \\
\text { 10 June } 2017\end{array}$ & \\
\hline
\end{tabular}

\section{Introduction}

Dietary requirement for polyunsaturated fatty acids of an insect was first observed by Fraenkel and Blewata in 1945. They reported that in presence of insufficient wheat gram oil in the diet, larval development as well as adult emergence became prolonged and the wings of which were partly or entirely lacking. Further research revealed that linoleic acid, the active substance in the wheat germ oil, was necessary for adult emergence and normal wing formation in adult insects (Fraenkel and Blewett, 1946). In a similar line of research studies, Vanderzant et al., (1957) confirmed that linoleic acid was more active compound as compared to linolenic acid for Pectinophora in prompting the emergence. Symptoms of linoleic acid deficiency were recorded both in Schistocerca and Locusta during final moult and wing formation (Dadd, 1960, 1961). Similarly, fewer adult emergence of Anthonomus grandis (Boheman) was recorded on fat-free diets than on diets containing fat. This was due to the difficulty of the adults to emerge from the pupal cases (Vanderzant, 1963). Rock et al., (1965) observed that addition of linseed oil on meridic diets of Argyrotaenia velutinana (Walker) promoted larval growth and decreased mortality at the time of pupation with increased normal adult emergence. The active substance in linseed oil was found to be linolenic acid, the effect of 
which proved almost equal to linoleic acid. A diet deficient to fatty acid may have bad impact on larval growth but the negative effect may surely be manifested during adult emergence i.e. emergence of faulty adults or adults with scale less or malformed wings (Dadd, 1970). Terrier and Grau (1972) reported that Trichoplusia ni (Hubn), Autographa californica (Speyer) had specific requirement of linolenic acid for normal wing formation while Heliothis zea (Boddie) required either linseed oil or wheat germ oil in the diets for the production of normal adults. Defatted wheat and alfalfa diet fortified with Linoleic acid reduced the wing syndrome (Crumpled wings) in Mamestra brassica Walker (Braken, 1982). No normal adult emergence was recorded in Spodoptera litura (Fabricius) reared on defatted dehusked lentil flour or dehusked Bengal gram flour. However, the diets fortified with minimum of half equivalent of Bengal gram oil or lentil oil produced almost $100 \%$ normal adult (Chenchaiah, 1987). Again, Linolenic acid played crucial role in over all development of pupae of Philosamia ricini (Priyadarshini and Revanasiddaiah, 2013). Not only in insects, this fatty acid plays an important role in human nutrition and used to prevent variety of diseases viz., cardiovascular, hypertension, inflammatory, auto immune disorders, depression and certain disrupted neurological functions (Christensen et al., 2005 and Ferrucci et al., 2006).

Therefore, keeping these views in this aspect, the present study was concentrated on effect of dietary linoleic acid and linolenic acid on the development and adult formation of Creatonotus gangis L.

\section{Materials and Methods}

The adults of $C$. gangis were collected from nucleus culture maintained in the laboratory. The male and female moths were allowed to copulate in a mating jar. The eggs were kept in an incubator fixed at $30 \pm 1^{\circ} \mathrm{C}$ and $85 \pm 5 \%$ r.h. for hatching. The newly hatched $(0-24 \mathrm{~h}$ old) larvae were used for the experiment.

The experiment was carried out on rice based semisynthetic diets fortified with different levels of linoleic acid and lenolenic acid viz. $0.050 \mathrm{~g}, 0.075 \mathrm{~g}, 0.100 \mathrm{~g}, 0.125 \mathrm{~g}, 0.150 \mathrm{~g}$ and $0.200 \mathrm{~g}$ per $100 \mathrm{~g}$ of diet, respectively. Both fatty acids were mixed separately on rice based diets while diets prepared without linoleic acid and linolenic acids were considered as control. Besides, larvae were also reared on berseem, the natural host plant, for comparing performances of different semisynthetic diets. The basic composition of diet was adopted from Tiwari and Bhattacharya (1987). The composition of basic diet per $100 \mathrm{~g}$ was commodity (Rice flour): $17.67 \mathrm{~g}$, Yeast powder: $3.08 \mathrm{~g}$, Sodium ascorbate: $0.31 \mathrm{~g}$, Methyl-p- hydroxybenzoate: $0.31 \mathrm{~g}$, Sorbic acid: 0.15g, Agar-agar: $1.54 \mathrm{~g}$, Formaldehyde (10\%): $0.15 \mathrm{ml}$ and water: $76.80 \mathrm{ml}$.

Emulsions of different levels of linoleic acid or linolenic acid were mixed with basic diet at $60^{\circ} \mathrm{C}$ to avoid degradation of the fatty acids. Each $100 \mathrm{~g}$ proportion of basic diet fortified with such emulsion of fatty acid prepared by shaking $1 \mathrm{ml}$ of ethanol (99.9\%) with $5 \mathrm{ml}$ of distilled water containing Tween-80 (1\%) along with $0.06 \% \alpha$-tocopherol (anti oxident). In control diets all the ingredients of the emulsion were added except linoleic acid and linolenic acid. The method of preparation of diet was presented in flowchart 1.

Newly hatched larvae were reared individually in plastic vials $(8.0 \times 3.0 \mathrm{~cm})$ fitted with screw caps containing different diets at $30 \pm 1{ }^{\circ} \mathrm{C}$ and $85 \pm 5 \%$ r.h. Thirty larvae were taken for rearing on each diet as well as the natural host plant (berseem). Larval survival was recorded at a regular interval till 
pupation and the foods were provided ad libitum. The adequacy of the diets were measured by the larval period, pupal period, per cent larval-pupal intermediate, per cent pupation, per cent adult emergence. Types of adult emergence were divided into five groups viz., a) adult with fully formed wings, b) adult having the wings with minor deformities, c) adult with severely deformed wings, d) partial emergence of adult from pupal case, e) failure of the adult to emerge from pupa (pupal case splitted).

Flow chart.1 Method for preparation of diet

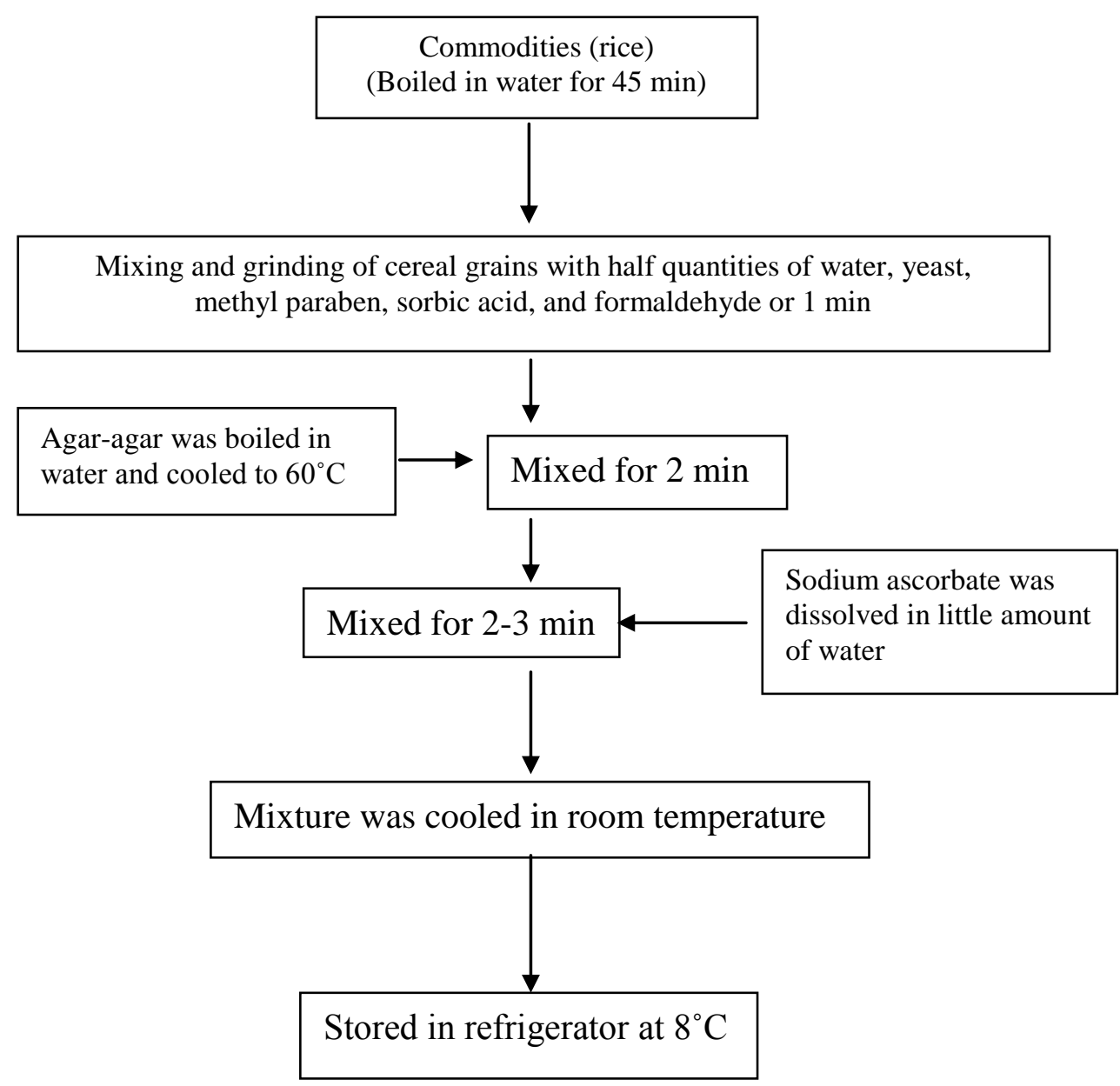




\section{Results and Discussion}

Results showed that larval survival on berseem remained higher as compared to semi-synthetic diets. Higher larval survival was also observed on diets fortified with fatty acids as compared to basic control diets.

No larval survival was recorded beyond 16 days after feeding (DAF) in basic control diet. Interestingly, gradual increase of larval survival was observed with the increased concentration of both fatty acids and the highest survival was recorded on $0.150 \%$ concentration. However, above this level survival of the larvae sharply decreased (Tables 1 and 2).

Observations on larval development revealed the prolonged larval period on semi-synthetic diets as compared to natural host plant (berseem). Data on larval period in control diet was not generated due to mortality of all larvae. Larval period in diets fortified different levels of linoleic acid ranged between 30.7 to 33.3 days.

Most prolong larval period was observed on diet fortified with $0.200 \mathrm{~g}$ linoleic acid followed by $0.050 \mathrm{~g}, 0.075 \mathrm{~g}, 0.100 \mathrm{~g}, 0.125 \mathrm{~g}$ and $0.150 \mathrm{~g}$ linoleic acid, respectively, while larval period on berseem was 21.2 days (Table 1). On the other hand, larval period extended to 34.6 days when the larvae reared on semi-synthetic diet fortified with $0.200 \mathrm{~g}$ linolenic acid, which was followed by $0.050 \mathrm{~g}$ (34.2 days), $0.075 \mathrm{~g}$ (33.5 days), $0.100 \mathrm{~g}$ (32.7 days), $0.125 \mathrm{~g}$ (32.3 days), $0.150 \mathrm{~g}$ (31.1 days) linolenic acid, respectively. Again, faster larval development was observed on barseem (21.1 days) than other treatments (Table 2).

Results showed that pupal period was minimum on semi-synthetic diet fortified with $0.150 \mathrm{~g}$ linoleic acid (8.1 days) which was followed by berseem (8.3 days). Pupal period in other diets was 9.3, 9.1, 8.7, 8.4 and 8.6 days in $0.050 \mathrm{~g}, 0.075 \mathrm{~g}, 0.100 \mathrm{~g}$ and $0.125 \mathrm{~g}$, respectively. Similar type of observation was also recorded in diets fortified with linolenic acid (Tables 1 and 2).

Larval-pupal intermediate was observed on different diets fortified with either linoleic acid or linolenic acid but no definite trend was found. Per cent pupation varies between 10.0 to 56.7 on different semi-synthetic diets fortified with different levels of linoleic acid. However, highest pupation observed on berseem (73.3\%) (Table 1). Similar results on percent pupation were also recorded in diets fortified with linolenic acid (Table 2).

Perusal of table 1 revealed that $66.7 \%$ adult emergence was observed on berseem when calculation based on initial number of release of larvae while percent adult emergence reaches to $90.9 \%$ if the calculation based on number of pupation.

In semi-synthetic diets, maximum adult emergence was recorded on diet fortified with $0.150 \mathrm{~g}$ linoleic acid. Gradual increase of percent adult emergence was also recorded with the increase of concentration of fatty acid. However, the concentration above $0.150 \mathrm{~g}$ linoleic acid showed very poor adult emergence. 
Table.1 Survival of $C$. gangis on rice based semi-synthetic diets fortified with different levels of linoleic acid

\begin{tabular}{|c|c|c|c|c|c|c|c|c|c|c|c|c|}
\hline \multirow[t]{2}{*}{ Treatments } & \multirow[t]{2}{*}{$\begin{array}{l}\text { Concentrations } \\
\text { (g/100g diet) }\end{array}$} & \multirow[t]{2}{*}{$\begin{array}{l}\text { \% Larval } \\
\text { survival\# }\end{array}$} & \multirow{2}{*}{$\begin{array}{l}\text { Larval } \\
\text { duration } \\
\text { (Days) }\end{array}$} & \multirow{2}{*}{$\begin{array}{l}\text { Pupal } \\
\text { period } \\
\text { (Days) }\end{array}$} & \multirow[t]{2}{*}{$\begin{array}{c}\% \\
\text { Pupation* }\end{array}$} & \multirow{2}{*}{$\begin{array}{c}\text { \% Larval- } \\
\text { pupal } \\
\text { intermediate* }\end{array}$} & \multirow[t]{2}{*}{$\begin{array}{c}\% \text { Adult } \\
\text { emergence* }\end{array}$} & \multicolumn{5}{|c|}{$\begin{array}{c}\text { Categories of adult emergence } \\
(\%)^{* *}\end{array}$} \\
\hline & & & & & & & & $\mathrm{a}$ & $\mathrm{b}$ & $\mathrm{c}$ & $\mathrm{d}$ & $\mathrm{e}$ \\
\hline \multirow{6}{*}{ 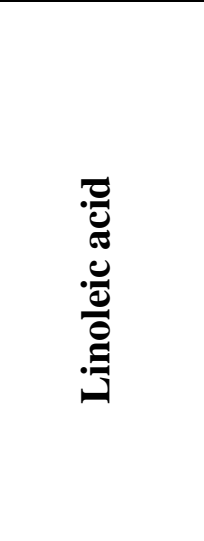 } & 0.050 & 23.3 & 32.4 & 9.3 & 13.3 & 3.3 & $6.7(50.0)$ & - & - & 50.0 & - & 50.0 \\
\hline & 0.075 & 36.7 & 32.2 & 9.1 & 20.0 & 3.3 & $13.3(66.6)$ & - & 50.0 & 50.0 & - & - \\
\hline & 0.100 & 40.0 & 31.9 & 8.7 & 33.4 & - & $26.7(70.0)$ & 28.6 & 28.6 & 28.6 & 14.2 & - \\
\hline & 0.125 & 60.0 & 31.6 & 8.4 & 46.7 & 3.3 & 36.7 (78.6) & 45.4 & 36.4 & 9.1 & 9.1 & - \\
\hline & 0.150 & 73.3 & 30.7 & 8.1 & 56.7 & - & $50.0(88.2)$ & 66.7 & 20.0 & 13.3 & - & - \\
\hline & 0.200 & 13.3 & 33.3 & 8.6 & 10.0 & - & $6.7(66.7)$ & - & 50.0 & - & - & 50.0 \\
\hline
\end{tabular}

\#: Data for larval survival considered at $16 \mathrm{DAF}$ as beyond this time period no larval survival recorded in control diet

*: Percentage was calculated from the number of initial release of larvae

Data in parentheses indicate the percentage values calculated from the pupal number

**: Percentage was calculated from the number of adult emerged 
Table.2 Survival of $C$. gangis on rice based semi-synthetic diets fortified with different levels of linolenic acid

\begin{tabular}{|c|c|c|c|c|c|c|c|c|c|c|c|c|}
\hline \multirow[t]{2}{*}{ Treatments } & \multirow[t]{2}{*}{$\begin{array}{l}\text { Concentrations } \\
\text { (g/100g diet) }\end{array}$} & \multirow[t]{2}{*}{$\begin{array}{l}\text { \% Larval } \\
\text { survival\# }\end{array}$} & \multirow{2}{*}{$\begin{array}{l}\text { Larval } \\
\text { duration } \\
\text { (Days) }\end{array}$} & \multirow{2}{*}{$\begin{array}{l}\text { Pupal } \\
\text { period } \\
\text { (Days) }\end{array}$} & \multirow[t]{2}{*}{$\begin{array}{c}\% \\
\text { Pupation* }\end{array}$} & \multirow{2}{*}{$\begin{array}{c}\text { \% Larval- } \\
\text { pupal } \\
\text { intermediate* }\end{array}$} & \multirow[t]{2}{*}{$\begin{array}{l}\% \text { Adult } \\
\text { emergence* }\end{array}$} & \multicolumn{5}{|c|}{$\begin{array}{l}\text { Categories of adult emergence } \\
(\%)^{* *}\end{array}$} \\
\hline & & & & & & & & $\mathrm{a}$ & b & $\mathrm{c}$ & d & $\mathrm{e}$ \\
\hline \multirow{4}{*}{ 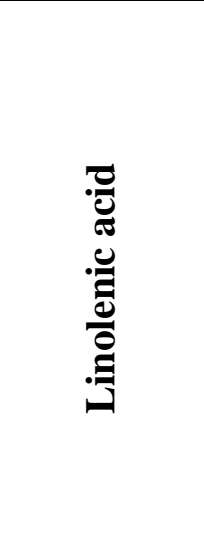 } & 0.075 & 56.7 & 33.5 & 8.8 & 26.7 & 6.7 & $20.0(75.0)$ & - & 33.3 & 33.3 & 16.7 & 16.7 \\
\hline & 0.125 & 67.7 & 32.3 & 8.3 & 43.3 & 3.3 & 36.7 (84.6) & 36.4 & 36.4 & 18.2 & 9.0 & - \\
\hline & 0.150 & 70.0 & 31.1 & 8.0 & 50.0 & 3.3 & 46.7 (93.7) & 60.0 & 33.3 & 6.7 & - & - \\
\hline & 0.200 & 36.7 & 34.6 & 8.2 & 13.3 & 10.0 & $6.7(50.0)$ & - & - & 50.0 & - & 50.0 \\
\hline
\end{tabular}

\#: Data for larval survival considered at $16 \mathrm{DAF}$ as beyond this time period no larval survival recorded in control diet

*: Percentage was calculated from the number of initial release of larvae

Data in parentheses indicate the percentage values calculated from the pupal number

**: Percentage was calculated from the number of adult emerged 
Type of adult emergence clearly indicated that more number of normal adults emerged with the increase of concentration of linoleic acid which was in order of $0.150 \mathrm{~g}>0.125 \mathrm{~g}>$ $0.100 \mathrm{~g}>\quad 0.075 \mathrm{~g}>\quad 0.050 \mathrm{~g}$. Similar observations were also reflected when the larvae reared on diets fortified with different levels of linolenic acid (Table 2).

The experimental findings revealed that linoleic or liolenic acid might have some effect on growth and development on $C$. gangis, but no doubt both fatty acids had major role on normal wing formation in adult. The results were in corroboration with Rock et al., (1965). Tiwari and Bhattacharya (1987) reported that addition of soybean oil in diet might contain factors that were responsible for normal wing development of S. obliqua while Chenchaiah and Bhattacharya (1998) recorded that adults of $C$. gangis obtained from rice based diets were all abnormal. The results clearly indicated that linoleic acid and linolenic acid had similar effect on growth and development as well as wing formation of C. gangis. This was an agreement with Fraenkel and Blewett (1946) who reported that linolenic and linoleic acids had similar effect on different lepidopteran stored grain insects. The results also revealed that linolenic and linoleic acids performed better upto a certain level of concentration beyond which both fatty acids might have some negative effect on the biology of $C$. gangis. This finding was an agreement with Ramsewak et al., (2001) and Ramos-López et. al. (2012) who reported insecticidal and insectistatic activities of linoleic acid against Aedes aegyptii, Helicoverpa zea, Lymantria dispar, Malacosoma disstria and Orgyia leucostigma.

\section{Acknowledgement}

The authors are thankful to Principal and Staff of Department of Plant Protection, Palli
Siksha Bhavana, Visva-Bharati, for providing facilities during the experiments.

\section{References}

Braken, G.K. 1982. The Bartha armyworm, Mamestea configurata (Lepidoptera: Noctuidae), Effects of dietary linolenic acid on pupal syndrome, wing syndrome, survival, and pupal fat composition, Can. Ent., 114: 567573.

Chenchaiah, K.C. 1987. Formulation of semisynthetic diets for Spodoptera litura (Fabricius) and Creatonotus gangis (Linnaeus), Ph.D. Thesis, G.B.Pant University of Agriculture and Technology, Pantnagar. 497 p.

Chenchaiah, K.C. and Bhattacharya, A.K. 1998. Semi-synthetic diet for rearing of Creatonotus gangis (Linnaeus). National Symposium on Entomology in $21^{\text {st }}$ century: Biodiversity, Sustainability, Environmental safety and Human health on April 30-May2, 1998. RAU, Udaipur, Rajasthan, India. pp.114.

Christensen J.H., Schmidt E.B., Molenberg D.T. 2005. Alpha Linolenic acid and heart rate variability in women examined for coronary artery disease. Nutr. Metab.Cardiovasc. Dis., 15:345351.

Dadd, R.H. 1960. The nutritional requirements of locusts Development of synthetic diets and lipid requirements. J. Insect Physiol., 4: 319-348.

Dadd, R.H. 1961. The nutritional requirements of locusts. Observations on essential fatty acids, chlorophyll, nutritional salt mixtures, and the protein and amino acid components of synthetic diets. J. Insect Physiol., 6:126-146. 
Dadd, R.H. 1970. Arthropod nutrition. In. Florkin, N. and Schear, B.T. eds., Chemical Ecology, Vol. V. Part A, Arthropoda. Academic press, New York and London. 11: 39-95.

Ferrucci, L., Cherubini, A., Bandinell, S. 2006. Relationship of plasma polyunsaturated fatty acids to circulating inflammatory markers. $J$. Clin. Endrocr. Metab., 91:439-446.

Fraenkel, G. and Blewata, M. 1945. Linoleic acid, alpha tocopherol and other fat soluble substances as nutritional factors for insects. Natur. London, 155: 392-393.

Fraenkel, G. and Blewett, M. 1946. Linoleic and Vitamin E and other fat soluble substances in the nutrition of certain insects (Ephestia kuehnietua, E. elutella, E. cautella and Plodia interpunctella (Lep.). J. Exp. Biol., 22: 172-190.

Priyadarshini, P.A. and Revanasiddaiah, H.M. 2013. Fatty Acid Composition in Pupae Oil of Philosamia ricini. Current Res. Microbiol. Biotech., 3: 95-97.

Ramos-López M. A., M. M. GonzálezChávez, N. C. Cárdenas-Ortega, M. A. Zavala-Sánchez and G. S. Pérez. 2012. Activity of the main fatty acid components of the hexane leaf extract of Ricinus communis against Spodoptera frugiperda. Afri. J. Biotechnol. 11: 4274-4278.

Ramsewak, R. S., M. G. Nair, S. Murugesan, W. J. Mattson and J. Zasada. 2001. Insecticidal fatty acids and triglycerides from Dirca palustris. $J$. Agri. Food Chem., 49: 5852-5856.

Rock, G.C., Patton, R.L. and Glass, E.H. 1965. Studies of the fatty acid requirement of Argyrotaenia velutinana (Walker). J. Insect Physiol., 11: 91-101.

Terriere, L.C. and Grau, P.A. 1972. Dietary requirements and tissue levels of fatty acids in three noctuidae, $J$. Insect Physiol.. 18: 633-647.

Tiwari, S.N. and Bhattacharya, A.K. 1987. Formulation of artificial diets for Bihar hairy caterpillar, Spilosoma obliqua Walker (Lepidoptera: Arctiidae). Memoirs of the Entomological Society of India. No. 12. I.A.R.I. New Delhi, India.

Vanderzant, E.S. 1963. Nutrition of boll weevil larva, J. Econ. Ent., 56: 357362.

Vanderzant, E.S.; Kerur, D. and Reiser, R. 1957. The role of dietary fatty acids in the development of the pink boll worm, J.Econ.Ent., 50: 606-608.

\section{How to cite this article:}

Palash Mondal and Somen Chakraborty. 2017. Effects of Dietary Linoleic and Linolenic Acids on Development and Adult Formation of Creatonotus gangis L. Int.J.Curr.Microbiol.App.Sci. 6(6): 2492-2499. doi: https://doi.org/10.20546/ijcmas.2017.606.296 